\title{
VALUE-BASED MANAGEMENT FOR REAL ESTATE DEVELOPERS' ACTIVITIES
}

\author{
Michał J. Kowalski \\ Faculty of Computer Science and Management \\ Wroctaw University of Science and Technology, Poland \\ e-mail: michal.kowalski@pwr.edu.pl
}

\section{Jan K. Kazak}

Institute of Spatial Management

Wrocław University of Environmental and Life Sciences, Poland

e-mail:jan.kazak@upwr.edu.pl

\begin{abstract}
Real estate development investments are characterized by a high value of projects, which in the event of irregularities in their implementation may result in significant losses for the economy. The lack of tools enabling ongoing control of real estate developers may result in disruptions in the operation of business entities on the real estate market, affecting the proper functioning of many stakeholders. The article proposes a method of measuring value for real estate companies. Accounting principles that regulate financial statements specify that they cannot be used directly to measure the value of a developer. The article proposes examples of corrections to financial statements supporting value measurement. When calculating value management measures, (i) adjustments excluding the impact of asset valuations, (ii) adjustments of settlement negative EVA of the investment phase, (iii) adjustments of advance payment of NPV of the project, and (iv) adjustments of excluding the impact of interest on foreign capital should be made. Examples of using these adjustments in a short-term housing project and a long-term commercial project were presented. The impact of the proposed adjustments on the comparison of formal financial statements and value measures for a large developer listed on the WSE was also discussed.
\end{abstract}

Key words: value based management, real estate market, economic value added.

JEL Classification: $C 58, R 38, R 51$.

Citation: Kowalski, M. J., \& Kazak, J. K. (2020). Value-based management for real estate developers' activities. Real Estate Management and Valuation, 28(4), 48-62.

DOI: https://doi.org/10.1515/remav-2020-0031

\section{Introduction}

Striving to build the value of invested capital remains the goal of modern enterprises in all kinds of industries. Many years of research on value management systems have enabled he development of numerous tools supporting the measurement and growth of enterprises to build shareholder value. However, their application requires the adaptation of measures which are aimed at taking into account the specificity of enterprises in various sectors of the economy in which they are applied. On the one hand, the use of this type of procedures is to provide a measurement of value appropriate to the individual business logic; on the other, it should not go against disturb the principles of objectivity and adequacy of measurement.

The real estate sector is among the sectors that could benefit from the mentioned experiences from value management research. The functioning of real estate enterprises is naturally based on projectoriented activities. However, the project-based approach has to be connected, in this case, with 
accounting law. In the case of the real estate sector, the moment of recognizing the financial profit of the implemented project is, in many cases, significantly postponed. Accounting policies ensure that financial profits are presented in a manner that is consistent with the conservatism principle, which, however, can be challenging for properly measuring value and implementing value management tools. One way to shorten the time between costs and revenues is to divide investment into separate stages. This approach allows part of the implemented investment project to be settled and balanced earlier. However, this solution is used for large investments consisting of many separate future real estates. This does not change the fact that, for each stage of the investment, there is still a deferral in the time of settlement enabling sustainable monitoring of the enterprise's processes.

The implementation of the idea of value-based management assumes ongoing monitoring of the expenses incurred by the enterprise and the value that has been generated as a result of the company's operations on the market. The implementation of such a management system could have a positive impact on increasing the level of economic security in the real estate sector, by providing decisionmakers with instruments to measure the economic situation of enterprises. The need to develop security mechanisms is confirmed by bankruptcy situations on the real estate market. Such situations do not happen often, but even an individual case may result in significant losses that affect many market stakeholders, such as future property owners, subcontractors or entities providing resources. Under Polish conditions, the bankruptcy of a company in 2014 resulted in financial irregularities of over PLN 770 million (Dzyuma-Zaremba, 2015), which confirms the need to improve the system of control over management processes in entities of the real estate sector.

The aim of this work was to analyze selected conditions of value-based management in a real estate development company and to propose a method for measuring the economic situation of the company using the concept of management through value. The impact of the applied revenue and cost accounting principles on value measurement was analyzed. The analysis is conducted in terms of providing measurement methods that will be consistent with the logic of value creation, which will ensure that measurement results can be used in management systems, including primarily incentive systems that are the basis for building relationships between owners and managers. The authors have developed examples of adjustments that can be useful in measuring values using value-based management. The developed approach to monitoring the economic situation of the enterprise was presented on the real values of two investments of a Polish enterprise implementing a project of a building complex including, in the first case, 189 apartments and, in the second case, 5 commercial estates.

\section{Literature review}

The beginnings of value-based management date back to the 1980s. From that moment, the ability to build value becomes the perspective of assessing the effectiveness of enterprises, which has been continuously dominant to this day (Kowalski, 2012). The point of view of the owner, who expects to multiply his assets by investing, takes on crucial importance in assessing economic efficiency (Rappaport, 1995). Capital and its cost are becoming a key economic category, accounting profits are beginning to be compared with the cost of capital invested (Copeland, 2000). Capital markets and investors are starting to make use of conclusions drawn in the groundbreaking work of Modiglianini and Miller (1958) and Sharpe (1964), on the cost of capital and assessing the ability of companies to build value when looking for investment opportunities. The ease of moving capital causes its constant migration (Kowalski \& Biliński, 2018). As a result, companies compete globally for capital and investors. Value becomes the basis for the assessment of management board activities by owners and corporate governance (Irala, 2005), and value management measures are permanently inscribed in managers' incentive systems (Biddle, 1999).

Years of research and practical verification have led to the definition of measures for the ongoing assessment of the ability of enterprises to build value. Myers (1996) even writes about the "war of measures" associated with the flourishing trend of value-based management, whose participants try to assure that the measure they propose creates value and is the best to measure the achievements of company. Concepts such as economic value added (EVA) or return on invested capital (ROIC) (Stewart, 1991) permanently become an element of measuring performance. The measures themselves have been the subject of several studies. For example, Sharma et al. (2010) identified and analyzed 112 
publications on EVA, which appeared in the years 1994-2007 in key corporate finance and management magazines.

Undoubtedly, the key to the use of indicators is their mathematical and repeatedly empirically verified relationship with market value (MV) and market value added (MVA). Income valuation based on discounting future EVAs is synonymous with valuation based on discounting future cash flows (Velez-Pareja \& Tham, 2003, Stancu, 2017). Thus, both approaches can be used to estimate MV or MVA. Nevertheless, the discussion about the empirical relationship between EVA and MVA seems endless, EVA-type measures have had a key impact on managing the performance appraisal of enterprises. Lehn and Makhija (1997) proved that EVA has the strongest correlation with rate on return among all measures of business activity. Similarly, Stewart (1994), de Medeiros (2005), Worthington and West (2004) showed EVA to better explain the behavior of share prices than other economic measures and that the rate of return on shares is better correlated with EVA than with profit or FOCF (Free Operation Cash Flow). In 2019, Obaidat (2019), based on empirical research conducted among companies listed on Amman Stock Exchange (ASE), recognized EVA as an enhancement tool to the existing traditional accounting performance measures, not as a substitute for them. However, there are a lot of studies indicating VBM measures not to explain the rate of return on shares, including EVA. Fernandez (2003) performed correlation analysis between EVA and MVA on 582 American companies. The study showed that a negative correlation was identified in 210 cases.

Measuring values itself and using EVA-type measures brings many conceptual problems. There is a consensus in the literature on the subject that data contained in financial statements are insufficient to measure value or even that the provisions of accounting law do not allow it. Stewart (1994) has suggested 164 possible adjustments to arrive at the adjusted date from financial statements for the calculation of EVA. The most popular areas of adjustment relate to investments, accounting for goodwill, asset revaluations, deferred income taxes, and pension (Worthington and West, 2004). However, Sharma $(2010$, ) based on studies on value measures, claims that there is a need to harmonize some adjustments that are required to be incorporated in the calculation of EVA. It is worth emphasizing that specific sectors of the economy create their own specific approach to calculating VBM measures, for example Geyser and Liebenberg (2003) for agribusinesses or Kim (2006) for healthcare companies.

Research on the use of VBM measures was carried out among companies in the real estate sector. Nappi-Choulet (2009) investigated the association between economic value added (EVA) and market value added (MVA) as proxies for the value generated by French listed companies and the proportion of real estate in their asset portfolio. The empirical results show that an increase in the proportion of real estate assets (over total assets) is negatively associated with EVA, but only for firms in service industries exhibiting low real estate intensity. The obtained results can be considered surprising. An increase in the value of assets should be treated as an investment by investors and effectively cause an increase in value. The reasons for the phenomenon observed by Nappi-Choulet can be seen in the accounting principles used in the real estate area, which the authors themselves emphasize.

Moreover, Parle et al. (2017) examine the economic performance of real estate property developers listed on the Australian Stock Exchange using a performance measure construct derived from the EVA model. Researchers have empirically demonstrated that most property companies did not generate sufficient annual profit to cover their cost of capital. Similarly, they see the reasons for these conclusions in the EVA measurement used. They point to the problems that can be caused by the accounting principles used by developers in measuring value, in particular AASB 116 Property, Plant \& Equipment and AASB 102 Inventories. Further, Parle recommends that EVA measurement principles be revised, and assets undervalued in the financial statements be revised (further adjustment to the EVA model is recommended to allow for any revaluation of real estate implemented in the other comprehensive income sections of the financial statements). This modification to EVA would provide a more appropriate metric for assessing the performance efficiency of property firms. Unfortunately, the authors did not indicate detailed rules for their application. Similarly, applications in the field of measuring VBM measures among companies operating in the real estate industry were published in previous works by Ooi and Liow (2002) researching Singapore Property Companies. Among their conclusions, they stated that by measuring value based on data contained in financial statements, we can understand the true economic performance of real estate. The necessity to look for methods to improve value measurement for real estate companies therefore seems necessary. 


\section{Methodological approach for value-based management in real estate sector}

The aim of the article is to present and discuss proposals for measuring value in a real estate enterprise which conducts development activities. The proposed method is to eliminate or reduce the difficulties in measuring the value associated with the impact of the conservatism principle on the shape of financial statements for this type of enterprise. The concept of economic value added as the most popular VBM measure was adopted as the starting point. Then, taking into account the conditions of accounting law and regulations affecting the shape of developer reports, as well as discussions with the management boards of these enterprises, corrections were proposed to individual components of economic added value. The presented solutions result from actual experience and many years of value measurements in a large capital group on the Warsaw Stock Exchange dealing in development activities. The adjustments presented in this work are the result of discussions regarding measuring the value held with both, the management of a company and representatives of shareholders.

The basic measurement of economic value added is made using the equation (Steward 1994):

$$
E V A=N O P A T-I C \times W A C C
$$

or

$$
\mathrm{EVA}=\mathrm{NOPAT}-\mathrm{CoC}
$$

or

$$
E V A=(R O I C-W A C C) \times I C
$$

where:

EVA

- Economic Value Added,

NOPAT - Net Operating Profit After Tax,

WACC - Weight Average Cost of Capital,

CoC - Cost of capital = IC $\times$ WACC,

ROIC - Return On Invested Capital,

IC - Invested Capital.

Risk associated with the possibility of changing future results, for example resulting from uncertainty about the prices obtained or meeting the project deadlines, is, in principle, reflected in the EVA measurement itself. In the EVA measurement, actual profits are compared to expected profits, and the expected profits depend directly on the risk of the business and are reflected in the cost of capital.

Steward and others point to the need to adjust the measurement by making adjustments to the financial statements at both the level of result measurement and the capital employed. The full formula should therefore read as:

$$
E V A=(N O P A T \pm A D J)-(I C \pm A D J) \times W A C C \pm A D J
$$

where:

ADJ - adjustments regarding financial statements.

We propose dividing EVA into three components when measuring the value, i.e.: operational EVA, land bank EVA and one-off EVA. The character of real estate development activity means that the reported value drivers can rely on fluctuations. For example, the purchase of land for new investments can abruptly increase the capital employed. Moreover, this land may, for a long time, burden the measurement of value at the expense of capital without generating any result or even burdening the result with its maintenance costs. The land may require preparation or concern future investment plans. On the other hand, the developer result may include one-off events related to the sale of an investment, e.g. an investment project (office or commercial) or a land bank or part of it. Observations and experiments carried out show that it is worth separating the measurement of value resulting from current operations from the cost of capital generated by the land bank as well as the value realized on one-off transactions usually related to the sale of assets. Therefore, we suggest that reporting for the real estate company could be carried out according to the following formula:

$$
E V A=\text { operational } E V A \pm \text { land bank EVA } \pm \text { one - off EVA }
$$




\section{S sciendo}

As indicated in the literature, development activities may require the application of standard corrections to financial statements. The application of corrections resulting from good will accounting or deferred tax exemptions are necessary, and can be implemented according to procedures widely described in the literature (Stewart, 1994; Worthington \& West, 2004; Kyriazis \&Anastassis, 2007). Regardless of different approaches described in the literature mentioned above, additional corrections resulting from the specifics of real estate development activities and accounting solutions used for developers are introduced in this study. We propose to make the following corrections:

1) Exclusion of the impact of asset revaluations.

2) Introduction of an investment account for short-term projects, e.g. housing, including activation and settlement during the negative EVA of the investment phase and advance payment during the EVA of the project together with its progress.

3) Introduction of an investment account for long-term projects, e.g. commercial projects (office, commercial, hotel) including activation and settlement in time of negative EVA investments.

4) Exclusion of the impact of interest on foreign capital in the valuation of assets and the cost of goods sold.

\subsection{Exclusion of the impact of asset revaluations}

The first proposed correction realizes the postulate that the calculation of the value should approximate the cash flow approach. The accounting principles adopted by most developers mean that most of them measure assets (land, owned commercial real estate) to fair value at each moment of the balance sheet valuation. In the financial statements of most developers maintained according to IFRS, we find items such as "the result of revaluation of real estate value". The impact of these items on the financial result can be significant. Even though the presentation of the value of real estate at fair value should be considered as the right approach, and the result of the revaluation carries a high cognitive value for the recipient of the financial statements, providing information about the impact of external macroeconomic factors connected with the real estate market on the situation of the enterprise, this presentation may, however, hamper the assessment of operational activity and self value measurement. This aspect is probably most often emphasized in the literature on the subject. Ooi and Liow (2002) indicate that fair value measurement is the reason why, in most cases, the developers surveyed in the market reached negative EVA values. Parle et al. (2017) propose the introduction of the so-called ROICr in the EVA calculation formula, where the lower case " $\mathrm{r}$ " is intended to signify the inclusion of revaluation amounts. The modified model would thus appear in the following terms:

$$
E V A=(R O I C r-W A C C) \times I C
$$

Parle et al. further indicate that the adjustment proposed is to accommodate the revaluation amount for the real estate assets by adding this to the NOPAT figure. This modification to the EVA would provide a more appropriate metric for assessing the performance efficiency of property firms. In this research we propose that the revaluation adjustment should not only concern the sphere of the result, but also exclude the impact of revaluations on the capital employed. The proposed correction could thus take the form of:

$$
E V A=(N O P A T \pm A D J r)-(I C \pm A D J r) \times W A C C
$$

where ADJr means excluding from the EVA account the impact of the revaluation amount for the real estate assets, both regarding the current result (NOPAT) and cumulative impact on the balance sheet and invested capital.

\subsection{Investment account for short-term projects}

The practice of applying the regulations introduced by the accounting law indicates ${ }^{1}$ that recognition of revenue from the sale of goods related to the transfer of risk and benefits arising from the sale of

\footnotetext{
${ }^{1}$ The introduction in 2009 of IFRIC 15 (Agreements for the Construction of Real Estate) by the International Financial Reporting Interpretations Committee (IFRIC 15 Real Estate Contracts, IFRIC 15) indicated guidelines as to whether a given contract implemented by a developer falls under the scope of IAS 11 Construction Contracts or IAS 18 Revenue. This distinction is of fundamental importance for the presentation of developers' results in financial statements and the moment of recognizing revenues from signed contracts. If IAS 11 applies, revenue is recognized on a percentage-of-completion basis provided that reliable estimates of construction progress and future costs can be made. In turn, if the agreement, in which the ability of buyers
} 
real estate occurs at the time of the acceptance of the premises by the buyer and after the seller has performed all contractual services to which the developer was contractually obliged as part of the sale (Dylag and Kucharczyk, 2011). As a result, the developer recognizes revenues from the sale of constructed premises at the moment:

1) obtaining permission to use the object,

2) obtaining payments from a customer in the amount usually less than $80 \%$ of the value of the premises sold,

3) handing over the premises for use to the buyer.

Until revenue is recognized in the income statement, the amounts of advances paid by buyers are recognized in the financial statements as liabilities.

Such accounting policies mean that value measurement based on data from financial statements may not properly reflect the logic of creating value in a development enterprise. Measurement made on the basis of financial statements would show the destruction of value for an example of a housing project, since the acquisition of land for the project throughout the entire investment phase. The value would not be revealed until the project is completed and the premises are owned by the buyers. In accordance with the superior conservatism principle for financial statements, activities related to the organization of the project, obtaining permits for its implementation, or project implementation remain not reflected in the financial profits, although they undoubtedly have the potential of value.

The purpose of the proposed adjustment is to take the value of effects from implemented shortterm investments, for example housing projects into account when measuring. We propose, for the purposes of measuring the value, the introduction of appropriate adjustments for:

1) the withdrawal of negative EVAs in the investment phase [1],

2) recognizing the EVA of the project, since its commencement by introducing advances on the planned EVA of the project [2].

The proposed correction will show the economic value generated by the project proportionally throughout the implementation period. The correction will be effective from the month or quarter in which, according to the provisions contained in the contract, it begins work related to the implementation of the project, to the month or quarter in which the investment was settled, i.e. the right to premises was issued to the last buyers.

The correction will concern [1] the withdrawal of negative results in the investment phase and the cost of capital employed in the investment phase. Then, the withdrawal of negative EVAs will be accounted for during the periods of sale of the premises, in proportion to the percentage of the premises transferred. At the same time, we suggest introducing an additional modification [2] to recognize current EVA advances from the project since its commencement. The basis for determining the amount of the advance should be the planned NPV of the project. Subsequently, the adjustment would be withdrawn at the project sales stage in proportion to the percent of premises sold and accounting profits recognized. Thus, in the sales phase, project profits would be adjusted by [1] activated negative EVA in the investment phase and [2] advances on the NPV of the project recognized in the investment phase. It should be noted that all adjustments made are charged to invested capital. In turn, their settlement causes their decrease from capital. As a result, the proposed correction mechanism does not change the NPV of the project, but only changes the distribution of residual profits obtained over time.

Applying the correction should reduce the risk of unexpected events in the project. For this reason, we suggest that the basis for calculating the correction are the financial plans approved by the institution financing the project. The total value of the advance should constitute a certain percent of the NPV of the project, which would additionally hedge the risk of adverse deviations from the plan. The adoption of such procedures for estimating the total value is intended to protect the owners' interests against excessive optimism of managers when assessing projects and their value potential. Therefore, the formula for calculating EVA is:

to influence the project is limited, it is, according to IAS / IFRS, a contract for the sale of goods and is subject to the regulations of IAS 18. In principle, revenues in this case will be recognized in the developer's income statement after the risk and control related to the goods are transferred to the buyer. 


$$
E V A j=(N O P A T j)-\left(I C j+\sum_{k=0}^{k=j-1} A D J_{k}^{n e g E V A}+\sum_{k=0}^{k=j-1} A D J_{k}^{a p E V A}\right) \times W A C C+A D J_{j}^{n e g E V A}+A D J_{j}^{a p E V A}
$$

where:

j - investment period,

$\mathrm{ADJ}_{\mathrm{k}}{ }^{\text {negEVA }}$ - correction made for activating negative EVA in the investment phase and its subsequent settlement in the sales phase,

$\mathrm{ADJ}_{\mathrm{k}} \mathrm{k}^{\mathrm{apEVA}} \quad$ - correction made for recognizing advanced payments on EVA in the investment phase and its subsequent settlement in the sales phase,

while it should be noted that:

1) $\mathrm{ADJ}_{\mathrm{k}}{ }^{\text {negEVA }}$ and $A D J_{k}{ }^{\text {apEVA }}$ in the investment phase are positive values and increase the calculation based on data from financial statements,

2) $A D J_{k}{ }^{n e g E V A}$ and $A D J_{k}{ }^{a p E V A}$ in the sales phase are negative values and reduce the calculation based on data from the financial statements,

$3)$ in the investment phase

$$
\begin{aligned}
& A D J_{j}^{n e g E V A}=(N O P A T j)+\left(I C j+\sum_{k=0}^{k=j-1} A D J_{k}^{n e g E V A}+\sum_{k=0}^{k=j-1} A D J_{k}^{a p E V A}\right) \times W A C C, \text { therefore } \\
& E V A j=A D J_{j}^{a p E V A} .
\end{aligned}
$$

\subsection{Investment account for long-term projects}

Long-term projects regarding the construction of such facilities as shopping centers, offices and hotels are burdened with similar recording problems that make measuring the value difficult. As in the case of housing investments, the investment phase means negative results and capital involvement. Then, during the project operation phase, the developer obtains revenues from the project operation and possibly the result on the sale of the object to the financial investor. For this type of projects, a correction analogous to that presented for housing projects, the withdrawal of negative EVAs in the investment phase and their subsequent settlement in the assumed period of business operation to be applied in the measurement of value. If the project is sold, the unadjusted value of the correction increases the investment cost.

\subsection{Exclusion of the inflow of interest on foreign capital}

An additional challenge from the point of view of measuring value are the solutions arising from accounting law in the scope of including interest expenses in the costs. In measuring the value, financial costs are replaced by the cost of capital employed. In order not to include the cost of financing twice, it seems reasonable to exclude these costs from the operating result and omit them from the measurement of the cost of capital included in inventory interest.

\section{Application of proposed method}

\subsection{Example of short-term project - housing investment}

A housing project consisting of 189 apartments with a total usable area of $8,870 \mathrm{~m}^{2}$ was chosen as an example. The duration of the project implementation was 2.5 years, i.e. 10 quarters, with the investment phase lasting 6 quarters. The last period of the project was the exploitation phase, in which premises were being sold. Table 1 presents the financial data of the project presented in the form as in financial statements. During the investment phase, the company increases the assets involved in the project to some point along with an increase in external debt that finances them. At the same time, since the third quarter, the level of debt has been stabilizing, and the company is implementing the project with funds paid by future buyers of the premises. In the investment phase, the company presents losses at the level of the operating result, does not generate revenues, and in accordance with the provisions of accounting law, not all costs incurred can be activated. With the start of the exploitation phase, operating income and profit appear in operating income.

Table 2 presents the measurement of value using the EVA indicator based on financial data from the reports presented in Table 1. WACC used by the analyzed company is the result of a calculation, which takes into account the financing structure, cost of equity estimated on the basis of the CAPM model and the cost of debt. In this case, the weighted average cost of capital is approved by the supervisory board and remains unchanged throughout the year. The calculations show that, in the 
initial phase, the company destroys the value, achieving negative EVA values. The company engages capital and reports negative earnings before interest and taxes (EBIT). The increase in value is only reported in the exploitation phase when the company begins to realize revenues and reduces the capital employed.

Table 1

Characteristics of the housing project

\begin{tabular}{lcccccccccc}
\hline Indicator [m PLN] & Q0 & Q1 & Q2 & Q3 & Q4 & Q5 & Q6 & Q7 & Q8 & Q9 \\
\hline Revenues & 0.0 & 0.0 & 0.0 & 0.0 & 0.0 & 0.0 & 35.3 & 13.4 & 1.7 & 0.0 \\
\hline EBIT & 0.0 & -0.3 & -0.4 & -0.4 & -0.4 & -0.4 & 7.9 & 2.9 & 0.3 & 0.0 \\
\hline Assets & 8.2 & 14.9 & 23.9 & 35.4 & 43.6 & 50.8 & 16.2 & 5.8 & 4.3 & 4.3 \\
\hline Debt & 0.0 & 3.8 & 10.5 & 13.9 & 14.9 & 9.2 & 0.0 & 0.0 & 0.0 & 0.0 \\
\hline
\end{tabular}

Source: own study.

Table 2

Value measurement based on financial statements

\begin{tabular}{lcccccccccc}
\hline \multicolumn{1}{c}{ Indicator } & Q0 & Q1 & Q2 & Q3 & Q4 & Q5 & Q6 & Q7 & Q8 & Q9 \\
\hline EVA [m PLN] & -0.4 & -0.6 & -0.8 & -1.0 & -1.1 & 7.2 & 2.7 & 0.2 & -0.1 & -0.4 \\
\hline NOPAT [m PLN] & -0.3 & -0.4 & -0.4 & -0.4 & -0.4 & 7.9 & 2.9 & 0.3 & 0.0 & -0.3 \\
\hline COC [m PLN] & -0.1 & -0.2 & -0.4 & -0.5 & -0.7 & -0.8 & -0.2 & -0.1 & -0.1 & -0.1 \\
\hline IC [m PLN] & 8.2 & 14.9 & 23.9 & 35.4 & 43.6 & 50.8 & 16.2 & 5.8 & 4.3 & 8.2 \\
\hline
\end{tabular}

Source: own study.

In Table 3 the EVA calculation after making the proposed correction is presented. Negative EVAs incurred in the investment phase are activated, and additionally, an advance on the planned value to be worked out as a result of the entire project is recognized. Both adjustments are settled in the exploitation phase in proportion to the sales of premises and revenues generated. The EVA ADJ values obtained show similar values in all quarters of the implemented project; they show significantly smaller fluctuations in relation to the EVA parameter calculated on the basis of financial data.

Table 3

Measuring the value after taking into account the proposed corrections

\begin{tabular}{lccccccccc}
\hline \multicolumn{1}{c}{ Indicator } & Q1 & Q2 & Q3 & Q4 & Q5 & Q6 & Q7 & Q8 & Q9 \\
\hline EVA ADJ [mPLN] & 0.9 & 0.9 & 0.9 & 0.9 & 0.9 & 1.0 & 0.4 & -0.1 & -0.1 \\
\hline NOPAT [mPLN] & -0.3 & -0.4 & -0.4 & -0.4 & -0.4 & 7.9 & 2.9 & 0.3 & 0.0 \\
\hline COC [mPLN] & -0.1 & -0.2 & -0.4 & -0.6 & -0.8 & -0.9 & -0.3 & -0.1 & -0.1 \\
\hline IC ADJ [mPLN] & 8.2 & 16.3 & 26.8 & 40.0 & 50.2 & 59.4 & 18.8 & 6.1 & 4.3 \\
\hline IC [mPLN] & 8.2 & 14.9 & 23.9 & 35.4 & 43.6 & 50.8 & 16.2 & 5.8 & 4.3 \\
\hline ADJ [mPLN] & 0.0 & 1.3 & 2.9 & 4.6 & 6.5 & 8.6 & 2.6 & 0.3 & 0.0 \\
\hline ADJ [mPLN] & 1.3 & 1.6 & 1.7 & 1.9 & 2.1 & -6.0 & -2.3 & -0.3 & 0.0 \\
\hline ADJ negative [mPLN] & 0.4 & 0.7 & 0.8 & 1.0 & 1.2 & -2.9 & -1.1 & -0.1 & 0.0 \\
\hline $\begin{array}{l}\text { ADJ advances payment } \\
\text { [mPLN] }\end{array}$ & 0.9 & 0.9 & 0.9 & 0.9 & 0.9 & -3.2 & -1.2 & -0.2 & 0.0 \\
\hline
\end{tabular}

Source: own study.

Table 4 lists the EVA values obtained - before adjustments and EVA ADJ including the proposed adjustments and differences between them. Note that the current value of both parameters is identical, i.e. the present value of the difference between EVA and EVA ADJ is equal to zero. Therefore, the proposed correction does not affect the assessment of investment effectiveness; it changes the presentation in time in order to better reflect the economic sense when assessing the ability to build value by a company. 
Comparison of results

\begin{tabular}{lcccccccccc}
\hline Indicator [mPLN] & Total & Q1 & Q2 & Q3 & Q4 & Q5 & Q6 & Q7 & Q8 & Q9 \\
\hline EVA & 6.1 & -0.4 & -0.6 & -0.8 & -1.0 & -1.1 & 7.2 & 2.7 & 0.2 & -0.1 \\
\hline EVA ADJ & 5.7 & 0.9 & 0.9 & 0.9 & 0.9 & 0.9 & 1.0 & 0.4 & -0.1 & -0.1 \\
\hline Difference & & -1.3 & -1.5 & -1.7 & -1.9 & -2.0 & 6.1 & 2.3 & 0.3 & 0.0 \\
\hline PV difference & 0.0 & -1.3 & -1.5 & -1.6 & -1.7 & -1.8 & 5.6 & 2.1 & 0.3 & 0.0 \\
\hline
\end{tabular}

Source: own study.

The results of measuring value on the basis of financial statements were presented graphically in Figure 1, taking into account the adjustment regarding the activation of negative EVA in the investment phase and as well as both the adjustment regarding the activation of negative EVA in the investment phase and the adjustment being an advance on the value generated as a result of the project. The correction regarding the activation of negative EVA in the investment phase means that value destruction is not reported in the investment phase, but there are still significant fluctuations in the reported value in the sales phase of the premises. It is only by applying both corrections that one can reduce fluctuations in value and reporting value increases more or less consistently since the beginning of the project.

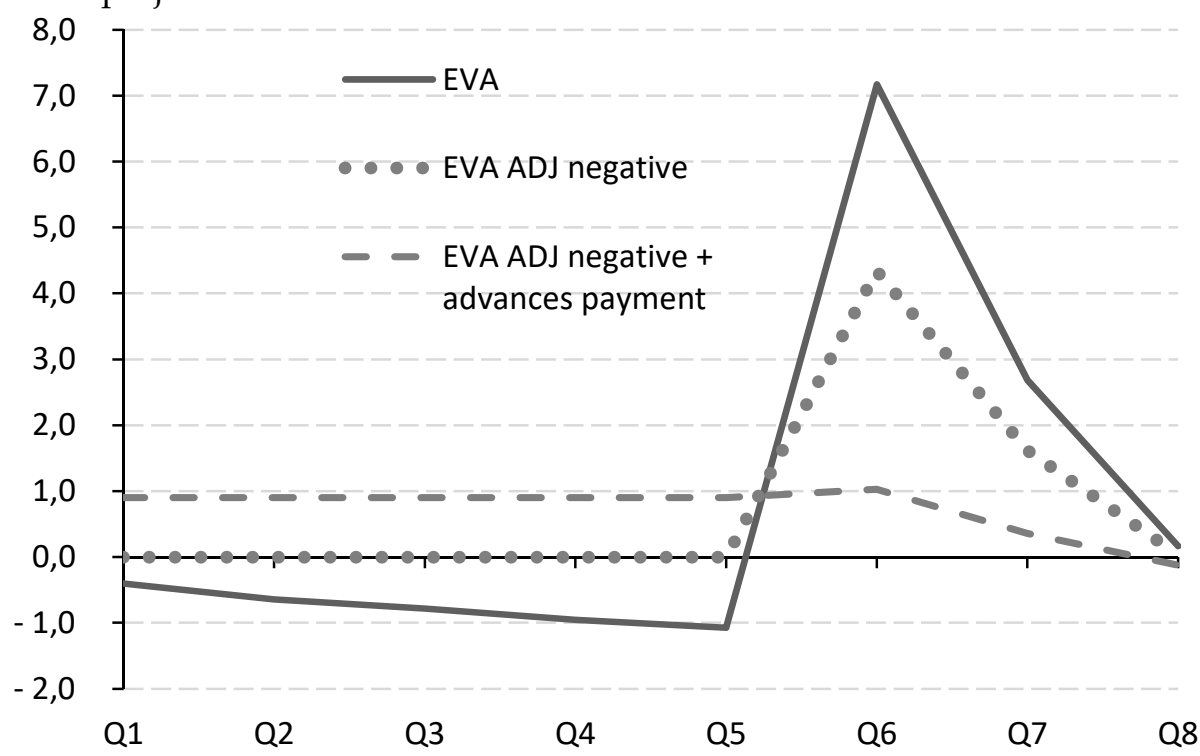

Fig. 1. A comparison of the effects of introducing the proposed corrections. Source: own study.

\subsection{Example of long-term project - commercial investment}

The second presented example concerns the implementation of an investment involving the construction of an office building. Table 5 presents key financial data. The investment phase lasted 4 quarters. During it, the company recorded negative results and engaged capital. At the same time, the first revaluation of the investment value was recorded in Q4, which resulted in the realization of the financial profit. Similar verification of the book value of the building, both increasing and decreasing, took place in the following quarters. Then, from the Q5 quarter, the office building operation phase is implemented - its gradual commercialization, which results in positive operating results. In the 12 th quarter, the office building is sold to a financial investor. The sale is carried out at book value, and therefore the company does not recognize the result on this account. Table 5 presents key financial data.

Table 6 presents the results of economic value added calculation based on accounting data. The investment phase is reported as value destruction. Property revaluations result in fluctuations in economic value added. 
Table 5

Characteristics of the commercial project

\begin{tabular}{lccccccccccccc}
\hline $\begin{array}{l}\text { Indicator } \\
{[m \text { PLN] }}\end{array}$ & Q0 & Q1 & Q2 & Q3 & Q4 & Q5 & Q6 & Q7 & Q8 & Q9 & Q10 & Q11 & Q12 \\
\hline EBIT & 0.0 & -0.4 & -0.4 & -0.3 & 4.6 & 0.1 & 0.9 & 0.7 & 0.4 & 0.7 & 0.7 & 0.7 & 0.9 \\
\hline $\begin{array}{l}\text { including } \\
\text { asset } \\
\text { revaluation }\end{array}$ & 0.0 & 0.0 & 0.0 & 0.0 & -4.5 & 0.0 & -0.5 & 0.0 & 1.1 & 0.0 & 0.0 & 0.0 & 0.0 \\
\hline Assets & 5.2 & 6.1 & 8.9 & 12.2 & 20.7 & 22.3 & 26.9 & 26.4 & 23.7 & 24.6 & 26.4 & 27.7 & 0.0 \\
\hline Debt & 0.0 & 1.1 & 4.2 & 7.6 & 12.4 & 14.1 & 18.0 & 17.6 & 16.0 & 16.3 & 16.7 & 17.9 & 0.0 \\
\hline
\end{tabular}

Source: own study.

Table 6

Value measurement based on financial statements

\begin{tabular}{lcccccccccccc}
\hline \multicolumn{1}{c}{ Indicator } & Q1 & Q2 & Q3 & Q4 & Q5 & Q6 & Q7 & Q8 & Q9 & Q10 & Q11 & Q12 \\
\hline EVA [mPLN] & -0.4 & -0.5 & -0.5 & 4.4 & -0.2 & 0.5 & 0.3 & 0.0 & 0.4 & 0.3 & 0.3 & 0.5 \\
\hline NOPAT [mPLN] & -0.4 & -0.4 & -0.3 & 4.6 & 0.1 & 0.9 & 0.7 & 0.4 & 0.7 & 0.7 & 0.7 & 0.9 \\
\hline COC [mPLN] & -0.1 & -0.1 & -0.1 & -0.2 & -0.3 & -0.3 & -0.4 & -0.4 & -0.4 & -0.4 & -0.4 & -0.4 \\
\hline IC [mPLN] & 5.2 & 6.1 & 8.9 & 12.2 & 20.7 & 22.3 & 26.9 & 26.4 & 23.7 & 24.6 & 26.4 & 27.7 \\
\hline
\end{tabular}

Source: own study.

Table 7 presents the effect of calculating the economic value added using the proposed adjustments. Negative results and the cost of capital in the investment phase have been activated and are subject to settlement in subsequent periods. Accounting revaluations of real estate values do not affect the measurement of value; they are excluded from the result and, at the same time, they correct the capital employed. The result on the sale of real estate appears in the last quarter, when the sale is actually carried out and the invested assets are converted into cash. A comparison of the obtained results is presented in Table 8 .

Table 7

Measuring the value after taking into account the proposed corrections

\begin{tabular}{lcccccccccccc}
\hline \multicolumn{1}{c}{ Indicator } & $\mathrm{Q} 1$ & $\mathrm{Q} 2$ & $\mathrm{Q} 3$ & $\mathrm{Q} 4$ & $\mathrm{Q} 5$ & $\mathrm{Q} 6$ & $\mathrm{Q} 7$ & $\mathrm{Q} 8$ & $\mathrm{Q} 9$ & $\mathrm{Q} 10$ & $\mathrm{Q} 11$ & $\mathrm{Q} 12$ \\
\hline EVA [mPLN] & 0.0 & 0.0 & 0.0 & 0.0 & -0.3 & 0.0 & 0.3 & 1.1 & 0.3 & 0.3 & 0.3 & 3.6 \\
\hline $\begin{array}{l}\text { NOPAT } \\
\text { [mPLN] }\end{array}$ & -0.4 & -0.4 & -0.3 & 4.6 & 0.1 & 0.9 & 0.7 & 0.4 & 0.7 & 0.7 & 0.7 & 0.9 \\
\hline COC [mPLN] & -0.1 & -0.1 & -0.1 & -0.2 & -0.3 & -0.3 & -0.3 & -0.3 & -0.3 & -0.3 & -0.4 & -0.4 \\
\hline IC [mPLN] & 5.2 & 6.5 & 9.9 & 13.6 & 17.7 & 19.3 & 23.3 & 22.7 & 21.0 & 21.8 & 23.5 & 24.6 \\
\hline $\begin{array}{l}\text { IC balance } \\
\text { sheet [mPLN] }\end{array}$ & 5.2 & 6.1 & 8.9 & 12.2 & 20.7 & 22.3 & 26.9 & 26.4 & 23.7 & 24.6 & 26.4 & 27.7 \\
\hline ADJ [mPLN] & & 0.4 & 1.0 & 1.4 & -2.9 & -3.0 & -3.6 & -3.7 & -2.7 & -2.8 & -2.9 & -3.0 \\
\hline ADJ [mPLN] & 0.4 & 0.5 & 0.5 & -4.4 & -0.1 & -0.6 & -0.1 & 1.0 & -0.1 & -0.1 & -0.1 & 3.0 \\
\hline $\begin{array}{l}\text { ADJ negative } \\
\text { [mPLN] }\end{array}$ & 0.4 & 0.5 & 0.5 & 0.2 & -0.1 & -0.1 & -0.1 & -0.1 & -0.1 & -0.1 & -0.1 & -0.9 \\
\hline $\begin{array}{l}\text { ADJ } \\
\text { revaluation } \\
\text { [mPLN] }\end{array}$ & & & & -4.5 & 0.0 & -0.5 & 0.0 & 1.1 & 0.0 & 0.0 & 0.0 & 3.9 \\
\hline
\end{tabular}

Source: own study.

\subsection{Application of the model in a Polish real estate development company}

The last element of the presented case study is the presentation of the financial results of the selected real estate development company from the perspective of ten years of experience in measuring and reporting value. The presented data relate to the historical data of the capital group listed on the 
Polish Stock Exchange. The company uses management based on value-based management, and therefore measures and evaluates the results from this point of view. The measurement is made taking into account the corrections indicated in the previous paragraphs. Table 9 presents the results of the formal financial statements. We are observing the gradual development of the company and the increasing scale of operations. After 4 initial years of negative operating results and increasing the state of assets, the company began to gradually increase the scale of operations. During the last year of activity, in connection with the use of market position, a significant increase in revenues while maintaining the level of costs is observed. As a result, we can see a $67 \%$ increase in revenues and a doubling of operating results without an increase in the assets involved.

Table 8

Comparison of results

\begin{tabular}{lccccccccccccc}
\hline $\begin{array}{l}\text { Indicator } \\
{[m \text { PLN }]}\end{array}$ & Total & Q1 & Q2 & Q3 & Q4 & Q5 & Q6 & Q7 & Q8 & Q9 & Q10 & Q11 & Q12 \\
\hline EVA & 5.2 & -0.4 & -0.5 & -0.5 & 4.4 & -0.2 & 0.5 & 0.3 & 0.0 & 0.4 & 0.3 & 0.3 & 0.5 \\
\hline EVA ADJ & 5.5 & 0.0 & 0.0 & 0.0 & 0.0 & -0.3 & 0.0 & 0.3 & 1.1 & 0.3 & 0.3 & 0.3 & 3.6 \\
\hline difference & & -0.4 & -0.5 & -0.5 & 4.4 & 0.1 & 0.5 & 0.1 & -1.0 & 0.1 & 0.1 & 0.1 & -3.1 \\
\hline $\begin{array}{l}\text { PV } \\
\text { difference }\end{array}$ & 0.0 & -0.4 & -0.5 & -0.4 & 4.1 & 0.1 & 0.5 & 0.0 & -0.9 & 0.1 & 0.1 & 0.1 & -2.6 \\
\hline
\end{tabular}

Source: own study.

Table 9

Real estate development company - financial data

\begin{tabular}{lcccccccccc}
\hline $\begin{array}{l}\text { Indicator } \\
{[\mathrm{kPLN}]}\end{array}$ & 2018 & 2017 & 2016 & 2015 & 2014 & 2013 & 2012 & 2011 & 2010 & 2009 \\
\hline Net Sales & 1028.0 & 614.2 & 279.9 & 200.3 & 129.7 & 94.0 & 30.0 & 51.1 & 17.5 & 7.1 \\
\hline $\begin{array}{l}\text { Operating } \\
\text { Profit }\end{array}$ & 213.4 & 82.1 & 35.6 & 25.0 & 8.3 & 0.5 & -6.6 & -3.9 & -1.0 & -2.3 \\
\hline $\begin{array}{l}\text { Total } \\
\text { Assets }\end{array}$ & 1811.8 & 1946.1 & 1695.9 & 1327.5 & 1153.4 & 992.6 & 818.7 & 799.8 & 613.2 & 295.9 \\
\hline $\begin{array}{l}\text { Total } \\
\text { Financial } \\
\text { Debt }\end{array}$ & 731.5 & 753.3 & 708.1 & 508.2 & 402.3 & 212.7 & 135.3 & 270.4 & 242.1 & 119.1 \\
\hline $\begin{array}{l}\text { Net } \\
\text { Earnings - } \\
\text { TTM }\end{array}$ & 165.7 & 48.2 & 53.2 & 25.2 & 20.9 & 9.8 & -9.5 & 0.7 & 1.1 & -33.8 \\
\hline $\begin{array}{l}\text { Operating } \\
\text { Margin - }\end{array}$ & $20.8 \%$ & $13.4 \%$ & $12.7 \%$ & $12.5 \%$ & $6.4 \%$ & $0.6 \%$ & $-21.9 \%$ & $-7.7 \%$ & $-5.7 \%$ & $-31.9 \%$ \\
TTM & & & & & & & & & & \\
\hline ROA & $9.1 \%$ & $2.5 \%$ & $3.1 \%$ & $1.9 \%$ & $1.8 \%$ & $1.0 \%$ & $-1.2 \%$ & $0.1 \%$ & $0.2 \%$ & $-11.4 \%$ \\
\hline
\end{tabular}

Source: own study.

Table 10 presents the results in the value reporting system. It should be noted that the measures of value are reported broken down into operating activities, relating to the bank of owned properties where no operating activity is currently carried out, i.e. development projects are not implemented, and regarding one-off events, i.e. in most cases of transactions related to the sale of real estate.

The distribution of value measures over time is different from formal results. The differences are presented graphically in Figure 2. The adopted reporting system takes into account, in the EVA of the current period, the value generated by projects initiated that do not generate revenues and results in the financial statements during this period. As a result, EVA measures are constant in the period 20132016, and EVA increases in recent years are definitely smaller than in the case of formal financial results. 
Table 10

Real estate development company - measures of value

\begin{tabular}{lcccccccccc}
\hline $\begin{array}{l}\text { Indicator } \\
{[\mathrm{kPLN}]}\end{array}$ & 2018 & 2017 & 2016 & 2015 & 2014 & 2013 & 2012 & 2011 & 2010 & 2009 \\
\hline EVA & 145.0 & 92.0 & 16.6 & 11.1 & 13.4 & 13.0 & -17.7 & -26.8 & -3.2 & -29.5 \\
\hline ROIC & $22 \%$ & $11 \%$ & $5 \%$ & $6 \%$ & $10 \%$ & $10 \%$ & $-3 \%$ & $0 \%$ & $5 \%$ & $-1 \%$ \\
\hline $\begin{array}{l}\text { Operational } \\
\text { EVA }\end{array}$ & 156.6 & 101.6 & 29.1 & 24.8 & 22.4 & 26.7 & -3.7 & -11.8 & -8.9 & -12.2 \\
\hline $\begin{array}{l}\text { Land bank } \\
\text { EVA }\end{array}$ & -11.6 & -9.5 & -17.2 & -13.0 & -13.0 & -13.7 & -14.3 & -15.0 & -15.6 & -17.3 \\
\hline $\begin{array}{l}\text { EVA One } \\
\text { Offs }\end{array}$ & 0.0 & -0.1 & 4.8 & -0.6 & 4.0 & 0.0 & 0.3 & 0.0 & 21.3 & 0.0 \\
\hline IC & 1113.7 & 1110.2 & 988.1 & 852.3 & 642.3 & 663.3 & 416.7 & 359.0 & 353.3 & 331.2 \\
\hline $\begin{array}{l}\text { IC Land } \\
\text { Bank }\end{array}$ & 165.7 & 155.1 & 255.0 & 199.5 & 185.6 & 195.5 & 203.7 & 214.7 & 222.9 & 247.2 \\
\hline NOPAT & 248.2 & 126.5 & 51.8 & 52.0 & 64.4 & 63.8 & -12.7 & 0.4 & 19.3 & -2.7 \\
\hline
\end{tabular}

Source: own study.

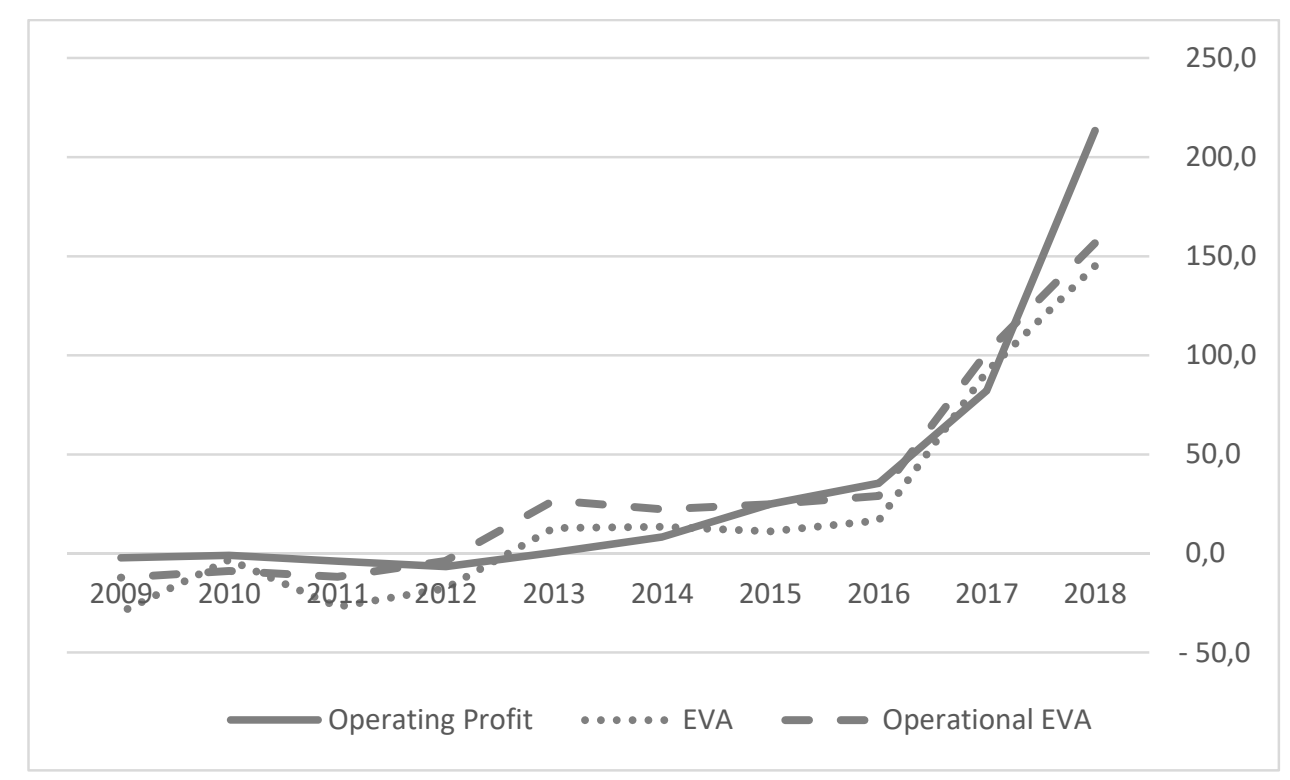

Fig. 2. Value measure of real estate development company. Source: own study.

The analysis of value measures clearly indicates three phases. The first phase is up until 2012 when the company was in the phase of value destruction. The financial results achieved did not compensate for the cost of capital employed. At the same time, we see a significant difference between the operational EVA and EVA of the entire enterprise related to the large capital of the land bank and the impact of one-off transactions. In the second phase, from 2013 to 2016, a stable level of value building is generated by the enterprise. During this period, the difference between value measures and accounting results is clearly marked. The projects launched by the company affect value reporting, while accounting results are only disclosed in later years. The third phase, from 2017, is where there is a significant increase in the result and value associated with the increase in the scale of implemented projects.

\section{Discussion and conclusions}

Value measurement is an important element of capital allocation and investor activities. In the case of real estate development operations, accounting solutions resulting from accounting law, including the revaluation of real estate value and recognition of the financial result once, at the time of transferring the ownership of real estate to buyers, mean that even estimating such measures of value as EVA or 
ROIC based on financial statements is very difficult or even impossible. The use of standard corrections recommended in the literature is not sufficient. Development activities require the introduction of dedicated adjustments tailored to the specifics of these enterprises and the accounting principles they use. In this study, we proposed that the following adjustments should be made when calculating value management measures:

1) excluding the impact of asset revaluations,

2) introduction of an investment account for short-term projects, e.g. housing, including activation and settlement during the negative EVA of the investment phase and advance payment during the EVA of the project together with its progress,

3) introduction of an investment account for long-term projects, e.g. commercial projects (office, commercial, hotel) including activation and settlement in time of negative EVA investment phases,

4) excluding the impact of interest on foreign capital in the valuation of assets and the cost of generating implemented investments.

In addition, in our opinion, the measurement of value measures in three streams is important in assessing value potential: (1) operational, (2) regarding the land bank, i.e. non-working capital most often associated with future investments, (3) one-off events most often associated with the sale of real estate. The use of the indicated adjustments allows to reduce difficulties in interpreting financial data in the developers' reports and their connections with the potential for value growth.

The findings of the use of value-based management in real estate sector may allow to avoid situations of inappropriate investments which may finally lead to bankruptcy. Going beyond the obtained test results, it could be considered how the application of the proposed solution may influence stability of socio-economic system connected with real estates by increasing transparency on housing market (Cellmer \& Trojanek, 2019). The issue of proper control of real estate development process is especially important taking into account pressure of both local (Źróbek, et al., 2014) and national (Stacherzak, et al., 2019) administration systems in order to redevelop land, reflected also in imbalance between supply and demand on real estates (Foryś \& Kazak, 2019; Broża, et al., 2020). High level of interest in proceeding redevelopment activity (Bieda, 2017) may affect inaccurate assessment of real estate development and created value (Kazak, et al., 2019; Krajewska \& Pawłowski, 2019).

The proposed method of measuring value has a wide application for both practice of managing real estate development companies as well as research on the development industry. The measurement of value for internal management needs should take into account the proposed adjustments. The proposed system allows estimating the value of projects initiated but as a result of accepted accounting solutions not disclosed in the financial result. At the same time, the proposed advance payment of values from a project in progress secures the measurement against the typical risk of development activity or excessive optimism of managers. The proposed adjustments can support the ongoing measurement of value for the needs of management, shaping relationships and the assessment of results on the owner - management line, including the building of incentive systems consistent with the concept of value-based management.

The proposed adjustments may be relevant when analyzing results of developers and assessing their potential to build value from the point of view of investors or other capital market stakeholders. The proposed adjustments are an attempt to quantify the measures of the value of carriers, such as the land bank, advancement of investment projects and the impact of valuation revaluations, on the financial statements used in developer valuations or investment recommendations in this industry. Therefore, the presented approach may constitute an important input to the research on models of forecasting value of real estate development, valuation of company shares as well as applications of this model for investment purposes.

Further research on the concept presented in the work may concern the development of algorithms for estimating the value of developers based on the proposed approach with the use of information published in the financial statements. It seems that most, if not all, information used in corrections is available in published financial documents, not directly in the reports, but in comments or supplementary notes. Estimating value measures in this way would allow the calculation of value measures for entire enterprise groups or the entire sector. That opens up an interesting and wide spectrum of further research. 


\section{References}

Kyriazis, D., \& Anastassis, C. (2007). The Validity of the Economic Value Added Approach: An Empirical Application. European Financial Management, 13(1), 71-100. https://doi.org/10.1111/j.1468-036X.2006.00286.x

Copeland, T., Koller, T., \& Murrin, J. (2000). Valuation: Measuring and managing the value of companies (3rd ed.). John Wiley \& Sons.

Biddle, G. C., Bowen, R. M., \& Wallace, J. S. (1999). Evidence on EVA. Journal of Applied Corporate Finance, 12(2), 69-79. https:// doi.org/10.1111/i.1745-6622.1999.tb00008.x

Bieda, A. (2017). Urban renewal and the value of real properties. Studia Regionalne i Lokalne, 69(3), 528.

Broża, N., Birnbaum, K., Castro, D. G., \& Kazak, J. K. (2020). Spatial Absorbency Assessment for Sustainable Land Development. Geomatics and Environmental Engineering, 14(2), 5-18. https://doi.org/10.7494/geom.2020.14.2.5

Cellmer, R., \& Trojanek, R. (2019). Towards Increasing Residential Market Transparency: Mapping Local Housing Prices and Dynamics. ISPRS International Journal of Geo-Information, 9(1), 2. https://doi.org/10.3390/ijgi9010002

de Medeiros, O. R. (2005). Empirical evidence on the relationship between EVA and stock returns in Brazilian firms. Available at SSRN 701421 https://doi.org/10.2139/ssrn.701421

Dylag, R., \& Kucharczyk, M. (2011). Recognising revenue from the construction of real estate in financial statements of developers in Poland. Accounting and Management Information Systems, 10(1), $25-42$.

Dzyuma-ZAremba, U., (2015). Gant Development SA - The Effectiveness of Bankruptcy Prediction Models in Case of Sudden Bankruptcy. Case Study. e-Finanse, 11(3), 45-57.

Fernandez, P. (2003). EVA, Economic profit and cash value added do not measure shareholder value creation. Journal of Applied Finance (JAF), 9(3), 74-94.

Foryś, I., \& Kazak, J. K. (2019). Absorption" or "Carrying Capacity" of Areas - Assessment Methods on the Example of Detached Housing Real Estate. Real Estate Management and Valuation, 27(2), 5-19. https://doi.org/10.2478/remav-2019-0011

Geyser, M., \& Liebenberg, I. E. (2003). Creating a new valuation tool for South African agricultural cooperatives. Agrekon, 42(2), 106-115. https://doi.org/10.1080/03031853.2003.9523614

Irala, L. R. (2005). EVA: The right measure of managerial performance. Journal of Accounting and Finance, 19(2), 77-87.

Kazak, J. K., Simeunović, N., \& Hendricks, A. (2019). Hidden Public Value Identification of Real Estate Management Decisions. Real Estate Management and Valuation, 27(4), 96-104. https://doi.org/10.2478/remav-2019-0039

Kim, G. W. (2006). EVA and Traditional Accounting Measures: Which Metric is a better predictor of market value of hospitality companies? Journal of Hospitality \& Tourism Research (Washington, D.C.), 30(1), 34-49. https://doi.org/10.1177/1096348005284268

Kowalski, M. J. (2012). Economic Value Added a topical issue for science and practice. Information System Architecture and technology/Library of Informatics of University Level Schools, Wrocław, $179-188$

Kowalski, M. J., \& Biliński, Ł. (2018). Interdependence Between Value Drivers and Value Migration Processes: Evidence from Warsaw Stock Exchange. Efficiency in Business and Economics. Springer.

Krajewska, M., \& Pawłowski, K. (2019). Coherent land policy and land value. Geomatics and Environmental Engineering, 13(4), 33-48. https://doi.org/10.7494/geom.2019.13.4.33

Lehn, K., \& Makhija, A. K. (1997). 1997, EVA, accounting profits, and CEO turnover: An empirical examination 1985-1994. Journal of Applied Corporate Finance, 10(2), 90-97. https://doi.org/10.1111/j.1745-6622.1997.tb00139.x

Myers, R. (1996). Metric Wars. CFO Magazine, October 1996.

Modigliani, F., \& Miller, M. H. (1958). The Cost of Capital, Corporation Finance and the Theory of Investments. The American Economic Review, 48, 261-297.

Nappi-Choulet, I., Missonier-Piera, F., \& Cancel, M. (2009). Value creation and the impact of corporate real estate assets: An empirical investigation with French listed companies. Journal of Corporate Real Estate, 11(2), 78-90. https://doi.org/10.1108/14630010910963124 
Obaidat, A. N. (2019). Is economic value added superior to earnings and cash flows in explaining market value added? An empirical study. International journal of business, accounting, $\mathcal{E}$ finance, 13(1).

Ooi, J., \& Liow, K. (2002). Real estate corporations: The quest for value. Journal of Property Investment $\mathcal{E}$ Finance, 20(1), 23-35. https://doi.org/10.1108/14635780210416246

Parle, G., Joubert, M., \& Laing, G. K. (2017). Measuring economic performance of Real Estate Developers in Australia:(A Longitudinal Study). Journal of New Business Ideas and Trends, 15, 1.

Rappaport, A. (1995). Creating Shareholder Value: A Guide For Managers And Investors. The Free Press, A Division of Simon \& Schuster Inc., New York.

Sharma, A. K., \& Kumar, S. (2010). Economic value added (EVA)-literature review and relevant issues. International Journal of Economics and Finance, 2(2), 200-220. https://doi.org/10.5539/ijef.v2n2p200

Sharpe, W. F. (1964). Capital asset prices: A theory of market equilibrium under conditions of risk. The Journal of Finance, 19(3), 425-442.

Stacherzak, A., Hełdak, M., Hájek, L., \& Przybyła, K. (2019). State Interventionism in Agricultural Land Turnover in Poland. Sustainability, 11(6), 1534. https://doi.org/10.3390/su11061534

Stancu, I., Obrejabrasoveanu, L., Ciobanu, A., \& Stancu, A. T. (2017). Are Company Valuation Models the Same?-A Comparative analysis Between the Discounted Cash Flows (DCF), the Adjusted Net Assets, Value and Price Multiples, the Market Value Added (MVA) and the Residual Income (RI) Models. Economic Computation and Economic Cybernetics Studies and Research, 51(3), 5-20.

Stewart, G. B. (1991). The Quest for Value. HarperCollins Publishers.

Stewart, G. B. (1994). EVAM: Fact and Fantasy. Journal of Applied Corporate Finance, 7(2), 71-84. https://doi.org/10.1111/j.1745-6622.1994.tb00406.x

Velez-Pareja, I., \& Tham, J. (2003). Do the RIM (Residual Income Model), EVA and DCF (Discounted Cash Flow) [Online] match? Available: https:/ / papers.ssrn.com/sol3/papers.cfm?abstract_id=379740

Worthington, A., \& West, T. (2004). Australian Evidence Concerning the Information Content of Economic Value-Added. Australian Journal of Management, 29(2), 201-223. https://doi.org/10.1177/031289620402900204

Źróbek, S., Trojanek, M., \& Źróbek-Różańska, A. (2014). Local authorities' activities aimed at attracting private investments: Effects, barriers and opportunities. Actual Problems of Economics, 3(3), 262-268. 